\title{
Vital population statistics based on length frequency analysis of the exploited Japanese eel (Anguilla japonica) stock in the Kao-Ping River, southern Taiwan
}

\author{
By Y.-J. Lin ${ }^{1}$ and W.-N. Tzeng ${ }^{1,2}$ \\ ${ }^{1}$ Institute of Fishery Science, College of Life Science, National Taiwan University, Taipei, Taiwan, ROC; ${ }^{2}$ Department of Life \\ Science, College of Life Science, National Taiwan University, Taipei, Taiwan, ROC
}

\begin{abstract}
Summary
Vital statistics such as growth, mortality, and maturity parameters are crucial in understanding the population dynamics of a species. A total of 7074 Japanese eels (Anguilla japonica) in the lower reach of the Kao-Ping River, southern Taiwan, were collected with eel tubes in $1998 \sim 2004$ and shrimp nets in 2004 2007. Data from 2004 were excluded due to mixed gear information and escapement of cultured eels; in subsequent years escaped cultured eels were identified and excluded from analyses. The estimated asymptotic length in the von Bertalanffy growth function $(84.5-110 \mathrm{~cm})$ was smaller, while the Brody growth parameter $\left(0.30-0.44\right.$ year $\left.^{-1}\right)$ was higher using electronic length frequency analysis (ELEFAN) than when using Shepherd's length composition analysis (SLCA). The total instantaneous mortality rate $(Z)$ was around 1 for periods $1998-2003$ and 2 year $^{-1}$ for 2005-2007 using length-converted catch curves. The 95\% confidence intervals of $Z$ did not overlap for two of the periods, suggesting that the mortality rates were significantly higher during 2005-2007, possibly due to the introduction of shrimp nets. The maturity function differed significantly between sexes, indicating that females become silver eels at a larger size. The Japanese eels in the lower reach of the Kao-Ping River were likely heavily exploited, thus management and conservation actions are strongly recommended.
\end{abstract}

\section{Introduction}

The Japanese eel, Anguilla japonica, is a catadromous fish widely distributed in Taiwan, China, Japan, and Korea (Tesch, 2003). The eels spawn in the tropical Pacific Ocean west of the Mariana Islands (Tsukamoto, 1992, 2006). The leaf-like larva, leptocephali, are transported passively via the North Equatorial and Kuroshio currents and metamorphose to the glass eel stage over the continental shelf and further develop into pigmented elvers in the estuary (Cheng and Tzeng, 1996). The elvers then either migrate upstream to freshwater habitats or remain in brackish estuaries as yellow eels. After 4-10 years the yellow eels begin sexual maturation and become silver eels with enlarged eyes and darkened body color (Han et al., 2001, 2003; Tzeng et al., 2002). These silver eels then migrate to the spawning grounds in the ocean to spawn and die (Tesch, 2003).

Vital population statistics such as growth parameters, total, natural, and fishing mortality and length at maturity are crucial in understanding population dynamics and making fisheries assessments (Quinn and Deriso, 1999; Jennings et al., 2001). Japanese eel populations, along with those of other temperate eel species, have been declining to historically low levels (Haro et al., 2000; Feunteun, 2002; Tatsukawa, 2003; Tseng et al., 2003; Dekker, 2004; Han and Tzeng, 2006). However, the availability of these statistics for Japanese eel stocks is limited relative to species such as the European eel A. anguilla (De Leo and Gatto, 1995; Svedäng, 1999; Dekker, 2004), American eel A. rostrata (Robitaille et al., 2003; Weeder and Uphoff, 2003), and Australian short-finned A. reinhardtii and long-finned $A$. dieffenbachii eels, and $A$. australis (Francis and Jellyman, 1999; Hoyle and Jellyman, 2002; Doole, 2005). Without appropriate vital population statistics, efficient and active management of $A$. japonica stocks may be difficult.

Traditional methods of studying the dynamics of exploited fish stocks were mostly based on age-structured data. However, use of computers and theoretical advantages of analytical methods based on length-frequency data led to their development during the 1980s (Jones, 1984; Gulland, 1987; Pauly, 1987; Pauly and Morgan, 1987) and widespread use in recent years (e.g. Özbilgin et al., 2004; Garćia and Duarte, 2006; Velasco et al., 2007). Length-frequency data is easier to obtain than age-structured data, and correctly ageing fishes in tropical waters may be difficult due to reduced seasonal growth contrast (Campana, 2001) or problems in interpreting otolith growth increments (Morales-Nin and Panfili, 2005). Thus, length-frequency methods were used to overcome such difficulties.

The lower reach of the Kao-Ping River in Taiwan (Fig. 1) is one of the most important fishing grounds for elvers, juveniles, and adult Japanese eels. Fishermen use bamboo eel tubes to harvest the juvenile and adult eels (Chang and Tzeng, 1990; Tzeng and Chang, 2001). In Taiwan, although great numbers are reared in aquaculture ponds, eels harvested in the wild attain prices 3-4 times higher than for cultured eels (Chang and Tzeng, 1990). Considerable quantities of both juveniles and adults are also caught as by-catch in shrimp nets in the lower reach, possibly because the eels follow the shrimp into the nets. Moreover, shrimp nets are widely used by eel fishermen because they are highly efficient in catching juvenile and adult eels (Lin and Tzeng, 2008), which further increases fishing pressure on the local eel stocks. However, information on growth, mortality, and maturity is limited, especially for yellow and silver eels. Thus, the path to meaningful management and restoration of A. japonica in Taiwan remains uncertain.

The study objective was to estimate the vital population statistics and evaluate the state of exploitation of $A$. japonica stock in the lower reach of the Kao-Ping River based on the length frequency data from the eel catch, 1998-2007. 


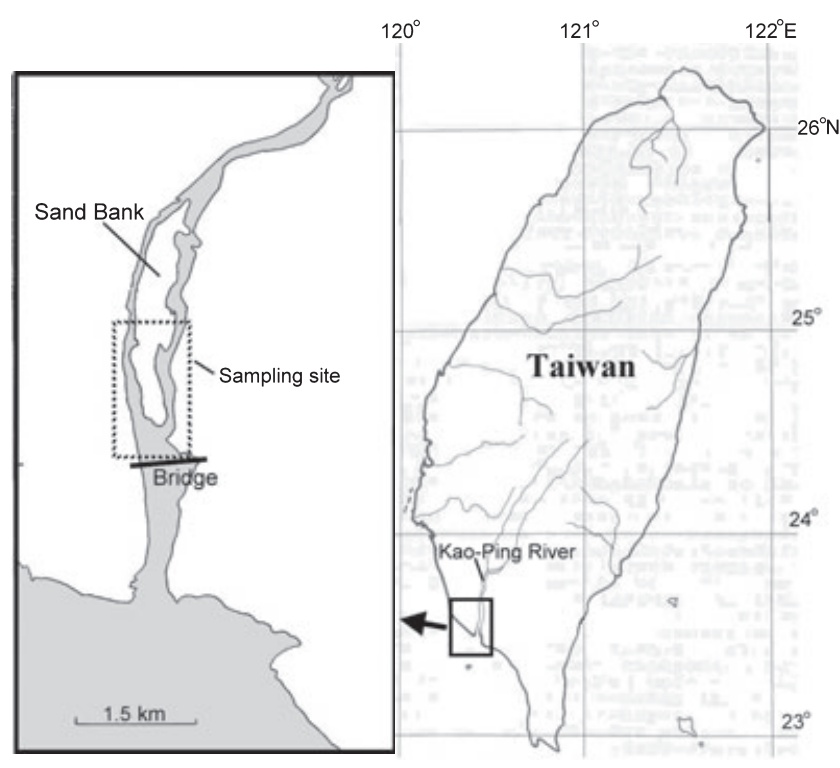

Fig. 1. Japanese eel Anguilla japonica sampling site, lower reaches of Kao-Ping River, southern Taiwan

\section{Materials and methods \\ Study area}

The Kao-Ping River is the second largest river in Taiwan with a length of $171 \mathrm{~km}$ and a drainage area of $3256 \mathrm{~km}^{2}$. Mean annual rainfall is $3046 \mathrm{~mm}$ and characterized by a dry season in winter and spring (October $\sim$ May) and a rainy season in summer and autumn (June $\sim$ Sept.). The rainfall is mainly contributed by the monsoon in early summer and by irregular typhoons during late summer and autumn. As a result, the river water level fluctuates in the mid- and upper reaches but is relatively stable in the lower reach. In the region where fishermen harvest the eels and sand shrimp, salinity is $10 \sim$ $30 \mathrm{ppt}$ and mean $( \pm \mathrm{SD})$ bottom temperature is $25.9 \pm 2.7^{\circ} \mathrm{C}$ (Chen, 2005).

\section{Sample collection and measurement}

Monthly eel catch in numbers was recorded from one cooperative fisherman using eel tubes during 1998-2004 and from another two fishermen using shrimp traps in 2004-2007 (Table 1). Gear information in 2004 was mixed and unable to be distinguished clearly. Moreover, the local eel stock was greatly influenced in 2004 by escaped cultured eels due to Typhoon Mindulle in July 2004 (Chu et al., 2006), and which might have influenced the estimation of vital parameters. This appeared to be most significant in 2004, decreasing substantially in 2005 and nearly disappearing in early 2006 (Lin and Tzeng, 2008). Moreover, the escaped cultured eels could be distinguished from wild eels by their different body coloration (Chu et al., 2006). Thus, data were separated into two periods: 1998-2003 and 2005-2007; data from 2004 was excluded from the length-frequency analysis. Escaped cultured eels were also excluded from analyses in 2005 and 2006.

Captured eels were anesthetized immediately with ice, measured for total length (to nearest $1 \mathrm{~mm}$ ) and total weight $(\mathrm{g})$, then transferred to the laboratory and frozen $\left(-20^{\circ} \mathrm{C}\right)$. After defrosting, sex was determined by gross inspection of the gonads, and the development stage (yellow or silver eels) was determined by the body color, enlarged eyes, and blackened pectoral fins (Han et al., 2003; Tesch, 2003).

\section{Growth}

Anguilla japonicus males are reported to have a mean growth rate in length of $>90 \%$ vs females in the Kao-Ping River (Tzeng et al., 2003), and 102\% in the Pearl River (Tzeng et al., 2000). Thus, the difference between sexes is not as significant as for other temperate eel species, and it was felt to be adequate to pool length data for both sexes in order to increase the sample size for analysis. Eel growth was described by the von Bertalanffy growth function (VBGF):

$$
L_{t}=L_{\infty}\left[1-e^{-K\left(t-t_{0}\right)}\right]
$$

where $L_{t}$ is the length at time $t, L_{\infty}$ is the asymptotic length, $K$ is the Brody growth coefficient, and $t_{0}$ is the initial condition parameter when the hypothetical length is zero (Quinn and Deriso, 1999).

The population maximum length, estimated following Formacion et al. (1992), was set as the preliminary value of the asymptotic length. In addition, the estimated population extreme length with $95 \%$ confidence intervals was also used to estimate $L_{\infty}$ according to Froese and Binohlan (2000):

$$
\log _{10}\left(L_{\infty}, \mathrm{cm}\right)=0.044+0.9841 \times \log _{10}\left(L_{\max }, \mathrm{cm}\right)
$$

Given the estimated maximum length as initial estimate of $L_{\infty}$, the preliminary value of $K$ was obtained using monthly catches-at-length data with 5 -cm intervals by length frequency analysis (FiSAT-ELEFAN) (Pauly, 1987) and Shepherd's length composition analysis (FiSAT-SLCA) (Shepherd, 1987), respectively. The response surface analyses of ELEFAN and SLCA were then used to search for the optimal combination of $L_{\infty}$ and $K$ (Gulland, 1987; Shepherd, 1987), in which the preliminary estimates of $L_{\infty}$ and $K$ were used as the inference points. These estimating procedures were completed using FiSAT software (Gayanilo et al., 1996). Growth performance index (Ø') (Pauly and Munro, 1984) was calculated as:

$$
\varnothing^{\prime}=\log _{\mathrm{e}}(K)+2 \log _{\mathrm{e}}\left(L_{\infty}\right)
$$

\section{Mortality}

Natural instantaneous mortality $(M)$ was estimated using Pauly's (1980) empirical formula (Gayanilo et al., 1996):

$$
\begin{aligned}
\log _{\mathrm{e}}(M)= & -0.0066-0.279 \log \mathrm{e}\left(L_{\infty}\right)+0.6543 \log _{\mathrm{e}}(K) \\
& +0.463 \log _{\mathrm{e}}(T), \mathrm{SD}_{(\log M}=0.245
\end{aligned}
$$

where $L_{\infty}$ and $K$ are VBGF parameters and $T$ is the mean environment temperature, i.e. $25.9^{\circ} \mathrm{C}$ in this study.

Total instantaneous mortality $(Z)$ was estimated using the length-converted catch curves developed from length frequency distributions (Pauly, 1990; Gayanilo et al., 1996), given the estimated value of VBGF parameters. The instantaneous fishing mortality $(F): F=Z-M$, the exploitation rate $(E): E=F \times Z^{-1}$ and the mean annual survival rate $(S)$ : $S=\exp (-Z)$.

\section{Sexual maturity}

The silver eels were sexually maturing in preparation for spawning in the ocean. The maturation process, represented by the silvering process, was assumed to depend on size rather than age (Vøllestad, 1992; Oliveira, 1999). It was further assumed that the corresponding parameters for the maturity equations were the same during the period from 1998 to 2006 
Table 1

Monthly eel catch by cooperative fishermen 1998-2007 in lower reach of Kao-Ping River

\begin{tabular}{|c|c|c|c|c|c|c|c|c|c|c|}
\hline & $1998^{\mathrm{T}}$ & $1999^{\mathrm{T}}$ & $2000^{T}$ & $2001^{\mathrm{T}}$ & $2002^{\mathrm{T}}$ & $2003^{T}$ & $2004^{\mathrm{TS}}$ & $2005^{S_{*}}$ & $2006^{\mathrm{S} *}$ & $2007^{\mathrm{S}}$ \\
\hline January & & 18 & & & & & 51 & & 205 & 545 \\
\hline February & & 40 & & 55 & 16 & & & & 155 & 640 \\
\hline March & & & & 95 & & & 15 & 154 & 84 & 411 \\
\hline April & & & & & & & 54 & & 61 & \\
\hline May & 16 & 3 & & 63 & & 30 & 66 & & 314 & \\
\hline June & & 11 & & 6 & & & 156 & 76 & 309 & \\
\hline July & & 9 & & & & 40 & 264 & 134 & 113 & 148 \\
\hline August & & 38 & 62 & & 152 & & 124 & 235 & & 50 \\
\hline September & & 71 & 16 & 30 & & 47 & 52 & & 99 & \\
\hline October & 22 & & 18 & 34 & & & 214 & 76 & 159 & \\
\hline November & & & & & & & 241 & 269 & 222 & 33 \\
\hline December & & & 16 & & & & 35 & 310 & 92 & \\
\hline Sum & $38(38)$ & $190(190)$ & 112 (112) & $283(283)$ & $168(168)$ & 117 (117) & $1272(1272)$ & 1254 (1092) & $1813(588)$ & $1827(841)$ \\
\hline $\mathrm{F}$ & 23 & 110 & 81 & 196 & 117 & 94 & 519 & 682 & 401 & 560 \\
\hline M & 4 & 24 & 11 & 28 & 28 & 9 & 689 & 206 & 39 & 9 \\
\hline $\mathrm{U}$ & 11 & 56 & 20 & 59 & 23 & 14 & 74 & 204 & 148 & 272 \\
\hline
\end{tabular}

*Escaped cultured eels were identified and excluded from the study.

Numbers in parentheses, number of eels sexed; Superscript T, eels caught by eel tubes; S, eels caught by shrimp nets; F, number of females; M, males; U, sexually undifferentiated eels. Individuals in 2004 were excluded due to mixed gear information and escaped cultured eels.

and between wild and escaped cultured eels in 2004 (Chu et al., 2006). They were also assumed to be the same between different types of gear. However, the silvering of $A$. japonicus was significantly different between sexes in that the silver females were generally larger and older (Han et al., 2003), thus the silvering process was fitted separately in females and males.

Let $\gamma\left(\mathrm{L}_{i}\right)$ be the proportion of the silver eels in the length class $L_{i}$, then the silvering pattern was fitted by two models:

(1) Logistic model:

$$
\gamma\left(L_{i}\right)=\frac{\exp \left(a+b L_{i}\right)}{\left[1+\exp \left(a+b L_{i}\right)\right]},
$$

where $a, b$ are parameters

(2) De Leo and Gatto's (1995) model:

$$
\gamma\left(L_{i}\right)=\frac{\gamma_{\max }}{\left[1+\exp \left(\frac{\lambda-L_{i}}{\eta}\right)\right]}
$$

where $\gamma_{\max }$ is the asymptotic maturation rate, $\lambda$ is the semisaturation constant which corresponds to the length at which the maturation rate $=0.5 \times \gamma_{\max } . \eta$ is a shape parameter which is inversely proportional to the slope of the curve at $L=\lambda$ (De Leo and Gatto, 1995). Note that the two models are identical when $\gamma_{\max }=1$. The optimal values of the parameters of the two equations were found by minimizing the sum of squared error using the Microsoft EXCEL SOLVER routine.

After the parameters of above models were estimated, the length at $50 \%$ maturity $\left(L_{m 50}\right)$ was calculated as:

$\hat{L}_{m 50}=\left\{\begin{array}{l}-\frac{\hat{a}}{\hat{b}}, \text { for logistic model } \\ \hat{\lambda}-\hat{\eta} * \log _{\mathrm{e}}\left(2 \hat{\gamma}_{\max }-1\right), \text { for De Leo \& Gatto's model }\end{array}\right.$

The null hypothesis that females and males have the same silvering process was tested by the analysis of the residual sum of squares (ARSS, Chen et al., 1992; Kimura, 2000) using the $F_{c}: F_{c}=\frac{S S H / P(Q-1)}{\operatorname{SSR}\left(H_{a}\right) /(n-Q P)}$ where $\operatorname{SSH}=\operatorname{SSR}\left(\mathrm{H}_{0}\right)-\operatorname{SSR}\left(\mathrm{H}_{\mathrm{a}}\right)=$ the sum of squared residuals for the null hypothesis - that of the alternative hypothesis. $\mathrm{P}=$ the number of parameters in the model (P equals 2 for the logistic model and equals 3 for De Leo \& Gatto's model), $Q=$ the number of groups compared (i.e. $=2$ for comparisons between sexes), and $\mathrm{n}=$ total sample size. $F_{c}$ for the logistic and De Leo \& Gatto models was calculated and compared with a critical value $F_{c r i t}=F_{P(Q-1), n-Q P, 1-0.5 \alpha}($ Kimura, 2000). Statistical significance level $(\alpha)$ was set at 0.05 .

\section{Results}

\section{Sample collection}

A total of 7074 eels were caught from 1998 to 2007, in which 4601 eels were sexed and their developmental stages (yellow or silver) determined (Table 1). Annual catch increased from around 130 eels in 1998-2003 and to more than 700 individuals after 2004, which coincided with introduction of the shrimp net to this area. Prior to 2007 most eels were sexed, with females dominating the catch from 1998 to 2003. However, in 2004, males increased due to cultured eel escapement (Chu et al., 2006). Also, the catch record from shrimp nets included more months than those from eel tubes (Table 1), implying that the fishing season for eel tubes was shorter than for the shrimp nets.

\section{Growth}

A total of 908 eels caught in 1998-2003 and 4894 eels in 20052007 were used for length-frequency analyses using FiSATELEFAN and FiSAT-SCLA. Observed and predicted maximum length, optimal combination of VBGF parameters, $L_{\infty}$ and $K$ and the growth performance index $\varnothing^{\prime}$ are shown in Table 2. Observed and predicted maximum length was 78.50 and $87.95 \mathrm{~cm}$ from 1998 to 2003, and 87.50 and $89.94 \mathrm{~cm}$ from 2005 to 2007 , respectively. Overlapping 95\% CIs for predicted maximum lengths indicated a statistically insignificant difference between the two periods. The predicted $L_{\infty}$ from $L_{\max }$ was $89.39 \mathrm{~cm}(95 \% \mathrm{CI}: 84.11-97.17 \mathrm{~cm})$ and $94.43 \mathrm{~cm}(95 \% \mathrm{CI}$ : $84.92-100.39 \mathrm{~cm}$ ) for 1998-2003 and 2005-2007, respectively. VBGF parameters $\left(L_{\infty}, K\right.$ and $\left.\varnothing\right)$ were estimated by ELEFAN as $101.00 \mathrm{~cm}, 0.33$ year $^{-1}$, and 8.12 , and by SLCA as $84.50 \mathrm{~cm}, 0.38$ year $^{-1}$, and 7.91 for eels from 1998 to 2003 . For eels caught from 2005 to 2007, the corresponding values were $110.00 \mathrm{~cm}, 0.30$ year $^{-1}$, and 8.20 , and $94.00 \mathrm{~cm}$, 
Table 2

Observed and predicted maximum length $\left(L_{\max }\right)$, corresponding estimate of asymptotic length $\left(L_{\infty}\right)$ from $L_{\max }$, estimates of VBGF growth parameters $\left(L_{\infty}\right.$ and $\left.K\right)$, growth performance index $(\varnothing)$ by length frequency analysis (ELEFAN) and Shepherd's length composition analysis (SLCA) and corresponding estimates of instantaneous total mortality rate $(Z)$, natural mortality rate $(M)$, fishing mortality rate $(F)$, exploitation rate $(E)$, and annual survival rate $(S)$ of Kao-Ping River Japanese eels, 1998-2007

\begin{tabular}{|c|c|c|c|c|}
\hline Period & 1998-2003 & & 2005-2007 & \\
\hline $\mathrm{N}$ & 908 & & 4894 & \\
\hline \multicolumn{5}{|l|}{$L_{\max }(\mathrm{cm})$} \\
\hline Observed (cm) & 78.50 & & 87.50 & \\
\hline Predicted $(\mathrm{cm})$ & $87.95(81.52-94.39)$ & & $89.94(82.31-97.57)$ & \\
\hline$L_{\infty}$ from $L_{\max }(\mathrm{cm})$ & 89.39 (84.11-97.17) & & $91.43(84.92-100.39)$ & \\
\hline Method & ELEFAN I & SLCA & ELEFAN I & SLCA \\
\hline \multicolumn{5}{|l|}{ Growth } \\
\hline$L_{\infty}(\mathrm{cm})$ & 101.00 & 84.50 & 110.00 & 94.00 \\
\hline$K\left(\right.$ year $\left.^{-1}\right)$ & 0.33 & 0.38 & 0.30 & 0.44 \\
\hline$\varnothing$ & 8.12 & 7.91 & 8.20 & 8.26 \\
\hline \multicolumn{5}{|l|}{ Mortality } \\
\hline$Z\left(\right.$ year $\left.^{-1}\right)$ & $1.13(0.89-1.36)$ & $0.90(0.78-1.03)$ & $1.99(1.76-2.28)$ & $2.08(1.92-2.26)$ \\
\hline$M\left(\right.$ year $\left.^{-1}\right)$ & 0.59 & 0.68 & 0.54 & 0.74 \\
\hline$F\left(\right.$ year $\left.^{-1}\right)$ & 0.54 & 0.22 & 1.45 & 1.34 \\
\hline$E(\%)$ & 47.8 & 24.4 & 72.6 & 65.0 \\
\hline$S(\%)$ & $32.3(25.7-41.1)$ & $40.7(35.7-45.8)$ & $13.7(10.3-17.4)$ & $12.5(10.4-14.7)$ \\
\hline
\end{tabular}

$\mathrm{N}$, number of eels caught. Numbers in parentheses, $95 \%$ confidence interval.

0.44 year $^{-1}$, and 8.26 (Table 2). $L_{\infty}$ estimate from ELEFAN was higher compared to SCLA and outside the $95 \%$ CI of $L_{\infty}$ from $L_{\max }$, while the $L_{\infty}$ estimate from SCLA fell into this range. Thus, the $K$ estimate from ELEFAN I was smaller than that from SCLA due to the negative correlation between $L_{\infty}$ and $K$. The estimates of $\varnothing$ were similar between periods and methods, except for the 1998-2003 period when the SLCA method gave the lowest value.

\section{Mortality}

Instantaneous total mortality rates $Z$, estimated from the length-converted catch curves based on growth parameters from ELEFAN and SLCA for eels caught from 1998 to 2003 were 1.13 year $^{-1}$ (95\% CI: 0.99-1.36) and 0.90 (95\% CI: $0.78-$ $1.03)$, respectively. The confidence intervals include uncertainties in the catch curves only, assuming correct growth parameter values (Fig. 2a,b). For 2005-2007, $Z$ values were estimated as 1.99 year $^{-1}(95 \%$ CI: $1.76-2.28)$ and $2.08(95 \%$ CI: 1.92-2.26), respectively (Fig. 2c,d).

The annual natural mortality rates $(M)$ from Pauly's empirical formula based on ELEFAN and SLCA growth parameters were 0.59 and 0.68 year $^{-1}$, respectively, in 19982003, and amounted to 0.54 and 0.74 year $^{-1}$ in 2005-2007. According to the $95 \%$ confidence interval of individual data in Pauly's regression these estimates of $M$ are statistically uncertain by a factor of 3 , when assuming correct growth parameters.

Instantaneous fishing mortality rates $(F)$ were derived as 0.54 and 0.22 year $^{-1}$ in 1998-2003, and 1.45 and 1.34 year $^{-1}$ in 2005-2007. The exploitation rates $(E)$ during $1998 \sim 2003$ for Japanese eels were estimated as 47.8 and $24.4 \%$, with annual survival rates $(S)$ of 32.3 and $40.7 \%$. After 2005 , exploitation rates increased to 72.6 and $65.0 \%$ with $S$ of 13.7 and $12.5 \%$, suggesting that fishing pressure increased on the eels after the use of shrimp nets began (Table 2).

\section{Maturity}

The 4601 eels sexed from 1998 to 2007 (Table 1) were used to calculate maturation rates (represented by the proportion of silver eels) at a given size class. Females at about $40 \mathrm{~cm} \mathrm{TL}$ started to become silver eels, this proportion increasing greatly from 50 to $70 \mathrm{~cm}$ TL (Fig. 3). All females larger than $80 \mathrm{~cm}$ were silver eels (Fig. 3a). Males began to silver at $35 \mathrm{~cm}$ TL, the proportions thereof increasing considerably with length so that all males larger than $70 \mathrm{~cm}$ were silver eels (Fig. 3b). Both the logistic and De Leo \& Gatto models fitted the original data well and were indistinguishable (Fig. 3). The slope $(b)$ of the logistic model was greater and the intercept $(a)$ smaller in females $\left(0.18 \mathrm{~cm}^{-1}\right.$ and -11.55$)$ than for males $\left(0.15 \mathrm{~cm}^{-1}\right.$ and -8.47). For the De Leo \& Gatto model, $\gamma_{\max }$ was similar for both males and females (1.00), while $\lambda$ was larger and $\eta$ was smaller for females $(64.54$ and $5.59 \mathrm{~cm})$ than for males $(57.41$ and $6.78 \mathrm{~cm}$ ). The length at $50 \%$ maturity for females $(64.54 \mathrm{~cm})$ was larger than for males $(57.41 \mathrm{~cm})$ (Table 3). Moreover, according to the ARSS, the silvering process differed significantly between the sexes for both the logistic and De Leo \& Gatto models $\left(F_{c}=33.56\right.$ for the logistic and 20.34 for the De Leo \& Gatto model, both $\mathrm{P}<0.0001)$.

\section{Discussion}

\section{Length-frequency analysis methods}

For adequate results on growth from length frequency analysis, a total of 1500 or more individuals collected over at least 6 months with an apparent shift in modal length over time is advisable (Pauly, 1987), as is a sample size of at least 10 times the number of length classes (Gerritsen and McGrath, 2007). In 2005-2007 the sample sizes were for most months sufficiently large enough to satisfy the Gerritsen and McGrath (2007) rule of thumb (Table 2). The change in fishing gear used in 2004 was believed to substantially alter the catchability of the eel, thus the data were separated into two periods for estimation of growth parameters. However, the estimation of $Z$ during 2005-2007 is likely biased due to apparent changes in mortality after 2004.

Due to the lower eel catch rate of the eel tubes, the sample size was low for 1998-2003, which may have influenced the estimation of growth parameters. But the temporal scale was still large, as eels were collected over a 24-month period, which 


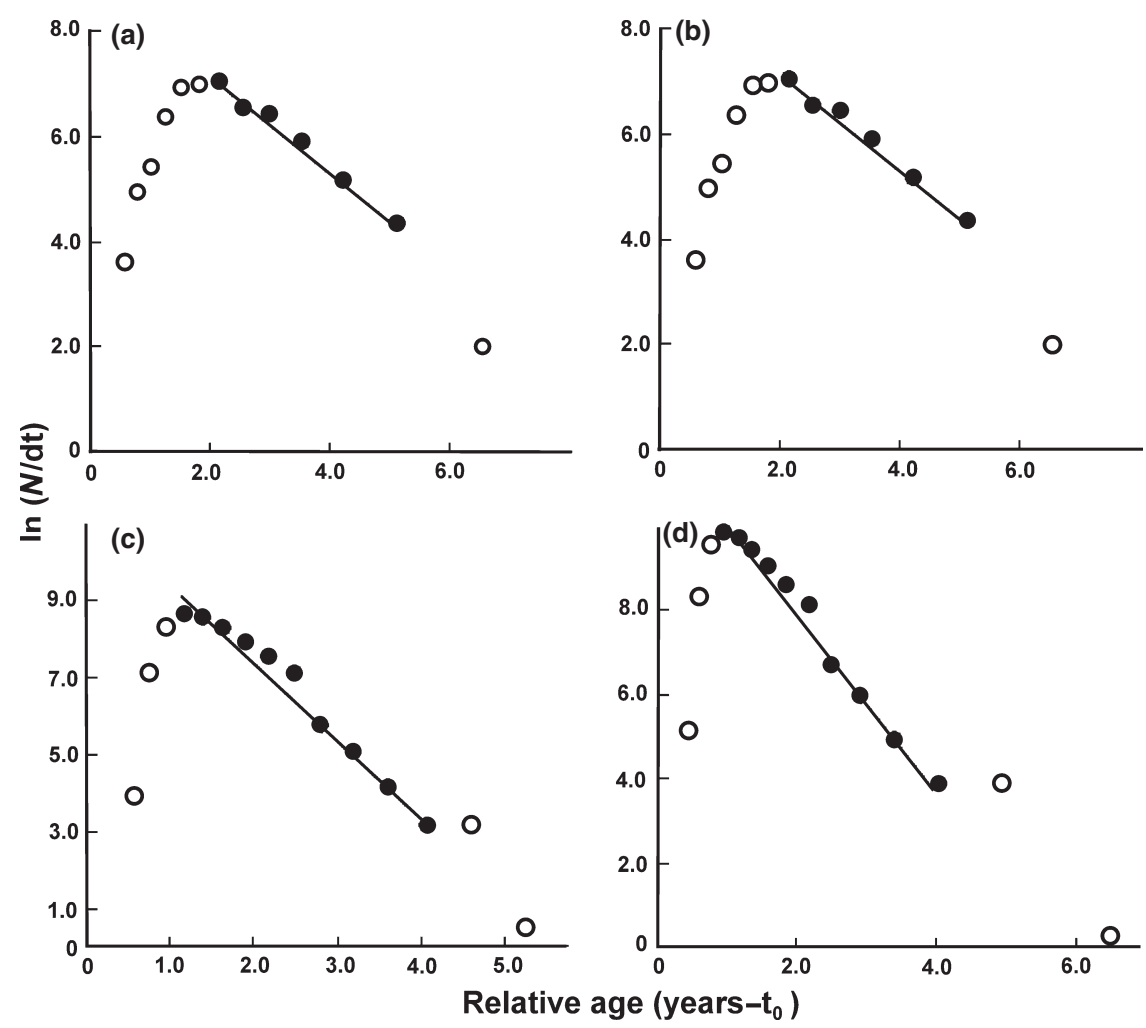

Fig. 2. Length-converted catch curves for data from (a) 1998-2003 using ELEFAN I; (b) 1998-2003 using SLCA; (c) 2005-2007 using ELEFAN I; and (d) 2005-2007 using SLCA
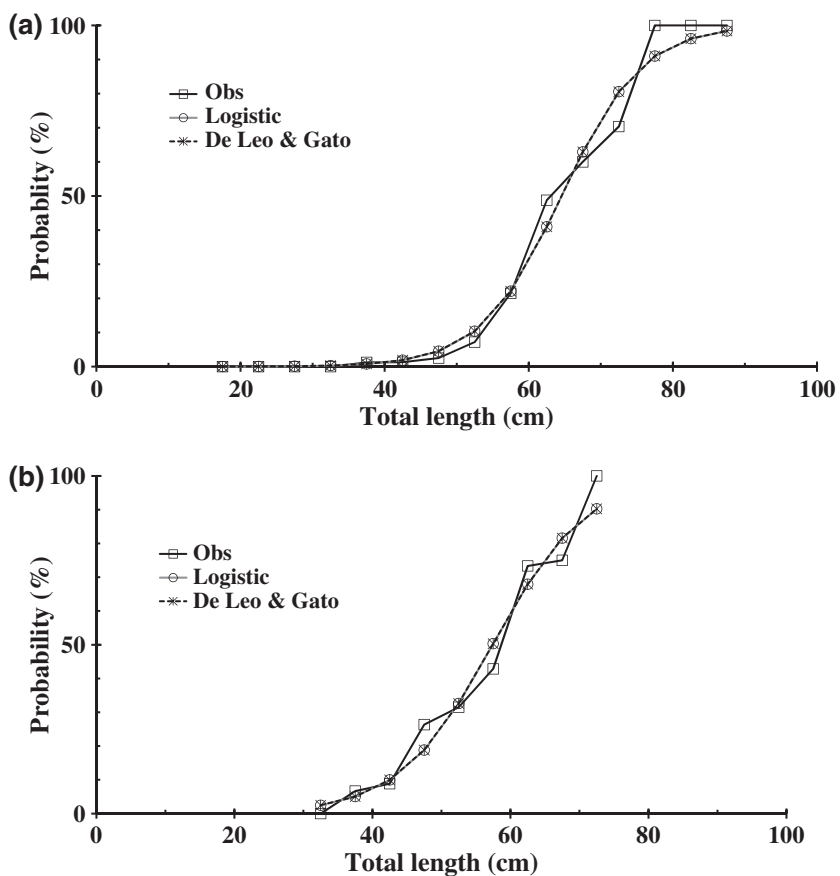

Fig. 3. Proportion of silver eels as a function of body length for (a) females and (b) males. Obs, observed in a given length class (squares on solid line); Logistic, predicted using logistic model (open circles on grey line); De Leo = predicted using the De Leo and Gatto (1995) model (asterisks on broken line)

might reduce the bias resulting from the small sample size in this period. Length class width $(5 \mathrm{~cm})$ was determined from a prior search of several possible widths $(1-10 \mathrm{~cm})$ to ensure distinct peaks in length distribution and clear changes in model length. However, the eel tube is more selective than the shrimp nets (Lin and Tzeng, 2008), perhaps making results from the
Table 3

Estimates of maturation parameters for the logistic and De Leo \& Gato models

\begin{tabular}{|c|c|c|c|c|}
\hline \multirow{2}{*}{$\frac{\text { Model }}{\text { Logistic }^{\mathrm{a}}}$} & \multicolumn{4}{|c|}{ Parameters } \\
\hline & $a$ & $b\left(\mathrm{~cm}^{-1}\right)$ & & $L_{50}(\mathrm{~cm})$ \\
\hline $\mathrm{F}$ & -11.55 & 0.18 & & 64.54 \\
\hline M & -8.47 & 0.15 & & 57.41 \\
\hline Pooled & -9.77 & 0.16 & & 63.11 \\
\hline De Leo \& Gato ${ }^{a}$ & $\gamma_{\max }$ & $\lambda(\mathrm{cm})$ & $\eta\left(\mathrm{cm}^{-1}\right)$ & $L_{50}(\mathrm{~cm})$ \\
\hline $\mathrm{F}$ & 1.00 & 64.54 & 5.59 & 64.54 \\
\hline M & 1.00 & 57.41 & 6.78 & 57.41 \\
\hline Pooled & 1.00 & 63.10 & 6.46 & 63.11 \\
\hline
\end{tabular}

$L_{50}=50 \%$ length at maturity. F, females; M, males; and pooled sexes. ${ }^{a}$ sex-separate models differed significantly from pooled the model.

1998 to 2003 period inconclusive and inconsistent between the different methods of analysis. Conversely, shrimp nets were less selective and the number of eels caught per month was much larger (mostly above 160 individuals, except for 2 months). Consequently, the use of length-frequency data was believed appropriate to estimate the vital population statistics of $A$. japonicus for the 2005-2008 period.

\section{Growth}

Anguilla japonicus growth was assumed to follow a von Bertalanffy growth function, which has been verified by Lin and Tzeng (2009a). The optimal combination of $L_{\infty}$ and $K$ were estimated by ELEFAN and SLCA using response surface analysis because the estimates of $L_{\infty}$ and $K$ are highly correlated (Gulland, 1987; Shepherd, 1987). Both methods may be affected by differences in growth strategies, individual variability in growth, seasonal oscillations of growth, variation 
in recruitment pattern, size-dependent selection, and the width of length classes (Isaac, 1990). The lower reach of the KaoPing River is tropical (Lin and Tzeng, 2009b), thus any seasonal oscillation in eel growth was assumed to negligible. Elvers recruit to the estuary regularly in winter from November to January and are not found after April (Tzeng, 1997). Thus, the recruitment season of the Japanese eel in Taiwan is considered to be stable, making the use the lengthfrequency data possible (Pauly, 1984).

$L_{\infty}$ estimated by ELEFAN was not included by the $95 \%$ CI of $L_{\infty}$ from $L_{\text {nax }}$, implying that $L_{\infty}$ from ELEFAN might be overestimated in this study. However, the uncertainty of growth parameters cannot be fully examined in this study. The variances of estimation of growth parameters were not given by FiSAT, thus statistical comparisons could not be conducted. It is still necessary to estimate the growth of A. japonicus using other data, e.g. lengths-at-age derived from annulus in the calcified structures that would enable comparisons of growth between sexes, time period and different data sources (Morales-Nin, 1989).

The values of $L_{\infty}$ and $K$ for Japanese eel vary considerably among different regions. In this study, $L_{\infty}$ was estimated between 84.5 and $112 \mathrm{~cm}$ when stages (i.e. yellow and silver eels) and sexes were pooled, while it was $98.2 \mathrm{~cm}$ for yellow eels from the Quilu River in southern China (Guan et al., 1994), and $55.7 \mathrm{~cm}$ for male and $77.5 \mathrm{~cm}$ for female silver eels from the Pearl River in southern China (Tzeng et al., 2000). Estimated $L_{\infty}$ values fell within the upper range of published values, while $K$ was higher $\left(0.29 \sim 0.45\right.$ year $\left.^{-1}\right)$ than in other studies $\left(0.07\right.$ year $^{-1}$ in Guan et al., 1994 and 0.21 year $^{-1}$ for males and 0.14 year $^{-1}$ for females in Tzeng et al., 2000). For Kao-Ping River eels the fishing pressure may be very high, perhaps reducing the intra-specific competition for food and suitable habitats and thus possibly enhancing individual growth rates. However, the relevance of this or other factors requires confirmation.

\section{Mortality}

Japanese eels in the Kao-Ping River probably faced a heavier fishing pressure after the introduction of shrimp nets. The $95 \%$ CI of $Z$ for 1998-2003 did not overlap with that for 2005-2007 with growth parameters derived from both ELEFAN and SLCA, suggesting a significant increase in $Z$ in 2005-2007. This may be contributed by the introduction of shrimp nets, which are less-selective than eel tubes and have been widely used by eel fishermen (Lin and Tzeng, 2008). In addition, $F$ and $E$ for $A$. japonicus were generally higher with a lower $S$ than for other fished eel species (Table 4). Thus, the Japanese eel stock in the lower reach of the Kao-Ping River may suffer higher fishing pressure than do the eels in other regions.

Hoyle and Jellyman (2002) predicted a reduction in spawner per recruit of $48 \%$ for female A. australis and $96.5 \%$ for female $A$. dieffenbachii under an annual $E$ of $10 \%$. Consequently, the impact of an annual exploitation rate larger than $60 \%$ in 2007 on the spawning biomass of the local Japanese eel stock might be severe. To enhance elver production, not only the harvest of elvers but also the biomass of eels in the river and escapement of silver eels to the spawning stock should be managed. Moreover, because of the time lag between a decrease in stock size and decrease in recruitment (7-14 years for A. anguilla; Feunteun, 2002) due to the catadromous nature of eels, where they spend about 1 year as migrating leptocephali and several years in freshwater or brackish waters, a precautionary approach (Russell and Potter, 2003) should be applied.

However, the estimates of $Z$ in this study still have a large uncertainty. Because $Z$ was estimated from a length-converted catch curve, the input of different growth parameters would obviously alter the shape of the converted catch curve and thus the estimates of $Z$ (Isaac, 1990). Also, $M$ was derived from Pauly's empirical formula rather than estimated directly from the population (e.g. mark-recapture experiment), and is correspondingly sensitive to the uncertainties in the growth parameters. Thus, the obtained high $M$ compared to other eel species (Table 4) is at least in part due to high values of the growth parameters. Moreover, the estimation of $Z$ was still under the influence of eel tubes for some years after the introduction of shrimp nets. The catch curves in 2005-2007 (Fig. 2c,d) appear to have a sudden drop after the relative age of 2.5 years, implying a sudden increase in $Z$ for older individuals. Studies to estimate mortality rates independent of these growth parameters are required to further evaluate the current exploitation rate of eels in the Kao-Ping River.

Table 4

Comparison of mean annual natural mortality $(M)$, fishing mortality $(F)$, total mortality $(Z)$, exploitation $(E)$, and annual survival rate $(S)$ among other eel species

\begin{tabular}{|c|c|c|c|c|c|c|c|c|}
\hline Species & Locality & $M\left(\right.$ year $\left.^{-1}\right)$ & $F\left(\right.$ year $\left.^{-1}\right)$ & $Z\left(\right.$ year $\left.^{-1}\right)$ & $E(\%)$ & $S(\%)$ & Note & References \\
\hline A. anguilla & $\begin{array}{l}\text { Valli di Conacchio } \\
\text { Lagoon, Italy }\end{array}$ & & & & & $30-90$ & $\begin{array}{l}30 \% \text { for age } 1 \\
\text { to age } 2 \text {, } \\
90 \% \text { for } \\
\text { other ages }\end{array}$ & $\begin{array}{l}\text { De Leo and Gatto, } \\
1995\end{array}$ \\
\hline A. anguilla & West coast, Sweden & 0.23 & 0.31 & 0.54 & 57 & 58 & & Svedäng, 1999 \\
\hline A. anguilla & $\begin{array}{l}\text { Ijsselmeer Lake, } \\
\text { Netherlands }\end{array}$ & & 0.14 to $>2$ & & & & $\begin{array}{l}\mathrm{F} \text { increases } \\
\text { with length }\end{array}$ & Dekker, 2000 \\
\hline A. australis & New Zealand & 0.038 & & & 10 & & $\begin{array}{l}E \text { increases } \\
\text { with length }\end{array}$ & $\begin{array}{l}\text { Hoyle and Jellyman, } \\
2002\end{array}$ \\
\hline A. dieffenbachii & New Zealand & 0.036 & & & 10 & & $\begin{array}{l}\text { E increases } \\
\text { with length }\end{array}$ & $\begin{array}{l}\text { Hoyle and Jellyman, } \\
2002\end{array}$ \\
\hline A. rostrata & Chesapeake Bay, US & 0.25 & 0.27 & 0.52 & 52 & 59 & & $\begin{array}{l}\text { Weeder and Uphoff, } \\
2003\end{array}$ \\
\hline A. rostrata & $\begin{array}{l}\text { St Lawrence River, } \\
\text { Canada }\end{array}$ & & & & $19-24$ & & & Caron et al., 2003 \\
\hline A. Japonica & $\begin{array}{l}\text { Kao-Ping River, } \\
\text { Taiwan }\end{array}$ & $0.53-0.74$ & $0.22-1.49$ & $0.90-2.08$ & $24-74$ & $12-41$ & & This study \\
\hline
\end{tabular}




\section{Maturity}

The maturity of Japanese eels, as represented by the silvering process, was assumed to be a function of size alone. This assumption seemed reasonable because the silvering of the eels was found to be dependent on size, not on age, for eel species such as A. anguilla (Vøllestad, 1992; De Leo and Gatto, 1995; Bevacqua et al., 2006), A. rostrata (Oliveira, 1999), A. australis, A. dieffenbachii (Jellyman, 2001; Hoyle and Jellyman, 2002), and A.japonica (Lin and Tzeng, unpubl. data). The silvering process was significantly different between female and male Japanese eels and the observed larger size of females at $50 \%$ maturity (Table 3 ) is consistent with the published data for this species (Tzeng et al., 2002, 2003; Han et al., 2003). Sexdimorphism in silver eels is common in A. anguilla, A. ros trata, A. australis and A. dieffenbachia (Poole and Reynold, 1996; Oliveira, 1999; Jellyman, 2001; Tzeng et al., 2003), perhaps related to sex-dependent life history strategies (Helfman et al., 1987).

In the logistic model, it is assumed that all individuals (i.e. $100 \%$ ) become silver eels at some older age or larger length class. The De Leo \& Gatto model is more plastic because of addition of $\gamma_{\max }$, the asymptotic probability of being silver eels, which can adjust the upper level of the silvering curve. Given that this study is the first to describe the maturation of A. japonica, no comparative published data are available for this species. For A. Anguilla, $\gamma_{\max }$ appeared to be more variable for females compared to males, being $0.12 \pm 0.03$ for females in the Valli di Comacchio Lagoon in Italy (De Leo and Gatto, 1995) and 0.60-1 in southern France (Bevacqua et al., 2006). For males in the two regions, $\gamma_{\max }$ generally approached 1 . For A. japonica in Kao Ping River in southern Taiwan, $\gamma_{\max }$ was 1 for both sexes in this study, suggesting that for $A$. anguilla and $A$. japonica, nearly all males tend to silver upon reaching some critical size, while for females the tendencies to become silver eels vary among regions and species. In other words, the conditions for females to become silver eels seem to be more plastic than for males.

\section{Conclusion}

Due to restrictions in the data set of the first time period and to the change in fishing method, the data on growth and mortality remain uncertain and require confirmation. In the absence of large environmental fluctuations, natural mortality rates were likely similar throughout the study period. The estimated decrease in survival rate, though uncertain in detail, was probably realistic due to the use of new fishing gear types that increased the fishing mortality and exploitation rate considerably.

\section{Acknowledgements}

This study was financially supported by the National Science Council, Taiwan (NSC94-2313-B-002-070). We would like to thank the cooperative fishermen and Dr S. L. Chang, Division of Biotechnology, Fisheries Research Institute, Taiwan for collecting the eel samples and providing the hydrological and gear information, as well as Prof. S. C. Fong, Institute of Marine Biology, National Sun Yat-sen University, Taiwan for giving valuable suggestions for analyzing length-frequency data with FiSAT; and our colleagues in the Fisheries Science, National Taiwan University, Taiwan for preparing the samples. Finally, we express our special thanks to B.M. Jessop for reviewing and giving helpful comments on the manuscript.

\section{References}

Bevacqua, D.; Mellià, P.; Crivelli, A. J.; De Leo, G. A.; Gatto, M. 2006: Timing and rate of sexual maturation of European eel in brackish and freshwater environments. J. Fish Biol. 69, (Suppl. C), 200-208.

Campana, S. E., 2001: Accuracy, precision and quality control in age determination, including a review of the use and abuse of age validation methods. J. Fish Biol. 59, 197-242.

Caron, F.; Verreault, G.; Rochard, E., 2003: Estimation of the population size, exploitation rate and escapement of silver-phase American eels in the St. Lawrence Watershed. In: Biology, management, and protection of catadromous eels. A. D. Dixon (Ed.). Am. Fish. Soc. Symp. 33, 235-242.

Chen, Y. D.; Jackson, D. A.; Harvey, H. H., 1992: A comparison of von Bertalanffy and polynomial functions in modeling fish growth data. Can. J. Fish. Aquat. Sci. 49, 1228-1235.

Chang, C. W.; Tzeng, W. N., 1990: Traditional fishing methods for eels in the river (in Chinese). Fish. Exten. NTU 12, 27-36.

Chen, P. H., 2005: Distribution, growth and reproduction of splendid ponyfish, Leiognathus splendens (Cuvier 1829) in the coastal waters off southern Taiwan. Master Thesis. National Sun Yat-sen University, Kaohsiung, Taiwan.

Cheng, P. W.; Tzeng, W. N., 1996: Timing of metamorphosis and estuarine arrival across the dispersal range of the Japanese eel Anguilla japonica. Mar. Ecol. Prog. Ser. 113, 89-96.

Chu, Y. W.; Han, Y. S.; Wang, C. H.; You, C. F.; Tzeng, W. N., 2006: The sex-ratio reversal of the Japanese eel Anguilla japonica in the Kaoping River of Taiwan: the effect of cultured eels and its implication. Aquaculture 261, 1230-1238.

De Leo, G. A.; Gatto, M., 1995: A size and age-structured model of the European eel (Anguilla anguilla L.). Can. J. Fish. Aquat. Sci. 52, 1351-1367.

Dekker, W., 2000: Impact of yellow eel exploitation on spawner production in Lake Ijsselmeer, the Netherlands. Dana 12, 25-40.

Dekker, W., 2004: Epilogue: worldwide decline of eel resources necessitates immediate action. Fisheries 28, 28-30.

Doole, J. G., 2005: Optimal management of the New Zealand longfin eel (Anguilla dieffenbachii). Aust J Agric Resour Econ 49, 395-411.

Feunteun, E., 2002: Management and restoration of European eel population (Anguilla anguilla): an impossible bargain. Ecol. Eng. 18, 575-591.

Formacion, S. P.; Rongo, J. M.; Sambilay, V. C., 1992: Extreme value theory applied to the statistical distribution of the largest lengths of fish. Asian Fish. Sci. 4, 123-135.

Francis, R. I. C. C.; Jellyman, D. J., 1999: Are mean size data adequate to monitor freshwater eel fisheries? Mar. Freshw. Res. 50, 355 366.

Froese, R.; Binohlan, C., 2000: Empirical relationships to estimate asymptotic length, length at first maturity and length at maximum yield per recruit in fishes, with a simple method to evaluate length frequency data. J. Fish Biol. 56, 758-773.

Garćia, C. B.; Duarte, L. O., 2006: Length-based estimates of growth parameters and mortality rates of fish populations of the Caribbean Sea. J. Appl. Ichthyol. 22, 193-200.

Gayanilo, F. C., Jr; Sparre, P.; Pauly, D., 1996: FAO-ICLARM stock assessment tools (FISAT) user's manual. FAO Comput. Inf. Ser. Fish. 8, 126.

Gerritsen, H. D.; McGrath, D., 2007: Precision estimates and suggested sample sizes for length-frequency data. Fish. Bull. 106, 116-120.

Guan, R.; Wang, X.; Ke, G., 1994: Age and growth of eels Anguilla japonica in a Chinese river. J. Fish Biol. 45, 653-660.

Gulland, J. A., 1987: Length-based methods in fisheries research: from theory to application. In: Length-based methods in fisheries research. D. Pauly, G. R. Morgan (Eds). ICLARM Conf. Proc 13, 335-342.

Han, Y. S.; Tzeng, W. N., 2006: Use of the sex ratio as a means of resource assessment for the Japanese eel Anguilla japonica: a case study in the Kaoping River, Taiwan. Zool. Stud. 45, 255-263.

Han, Y. S.; Tzeng, W. N.; Huang, Y. S.; Liao, I. C., 2001: Silvering in the eel: changes in morphology, body fat content and gonadal development. J. Taiwan Fish. Res. 9, 119-127. 
Han, Y. S.; Liao, I. C.; Huang, Y. S.; He, J. T.; Chang, C. W.; Tzeng, W. N., 2003: Synchronous changes of morphology and gonadal development of silvering Japanese eel Anguilla japonica. Aquaculture 219, 783-796.

Haro, A.; Richkus, W.; Whalen, K.; Hoar, A.; Busch, W. D.; Lary, S.; Brush, T.; Dixon, D., 2000: Population decline of the American eel: implication for research and management. Fisheries 25, 7-16.

Helfman, G. S.; Facey, D. E.; Hales, L. S., Jr; Bozeman, E. L., Jr, 1987: Reproductive ecology of American eel. In: Common Strategies of Anadromous and Catadromous Fishes, M. D. Bethesda, M. J. Dadswell, R. J. Klauda, C. M. Moffit, R. A. Saunders, R. L. Rulifson, J. E. Cooper (Eds). Am. Fish. Soc. Symp. 1, 42-56.

Hoyle, S. D.; Jellyman, D. J., 2002: Longfin eels need reserves: modeling the effects of commercial harvest on the stocks of New Zealand eels. Mar. Freshw. Res. 53, 887-895.

Isaac, V. J., 1990: The accuracy of some length-based methods for fish population studies. ICLARM Technical Report 27.

Jellyman, D. J., 2001: The influence of growth rates on the size of migrating female eels in Lake Ellesmere, New Zealand. J. Fish Biol. 58, 725-736.

Jennings, S.; Kaiser, M. J.; Reynold, J. D., 2001: Marine fisheries ecology. 1st edn. Blackwell Science, Maiden, MA.

Jones, R., 1984: Assessing the effects of changes in exploitation pattern using length composition data (with notes on VPA and cohort analysis). FAO Fish. Tech. Pap. 256.

Kimura, D. K., 2000: Using nonlinear functional relationship regression to fit fisheries models. Can. J. Fish. Aquat. Sci. 57, $160-170$.

Lin, Y. J.; Tzeng, W. N., 2008: Effects of shrimp net and cultured eels on the wild population of Japanese eel Anguilla japonica in KaoPing River, Taiwan. J. Fish. Soc. Taiwan 35, 61-73.

Lin, Y. J.; Tzeng, W. N., 2009a: Modelling the growth of Japanese eel Anguilla japonica in the lower reach of the Kao-Ping River, southern Taiwan: an information theory approach. J. Fish Biol. 75, 100-112.

Lin, Y. J.; Tzeng, W. N., 2009b: Validation of annulus in otolith and estimation of growth rate for Japanese eel Anguilla japonica in tropical southern Taiwan. Environ. Biol. Fish 84, 79-87.

Morales-Nin, B., 1989: Growth determination of tropical marine fishes by means of otolith interpretation and length frequency analysis. Aquat. Living Resour. 2, 241-253.

Morales-Nin, B.; Panfili, J., 2005: Seasonality in the deep sea and tropics revisited: what can otoliths tell us? Mar. Freshw. Res. 56, 585-598.

Oliveira, K., 1999: Life history characteristics and strategies of American eel, Anguilla rostrata. Can. J. Fish. Aquat. Sci. 56, 795-802.

Özbilgin, H.; Tosunoglu, Z.; Bilecenoglu, M.; Tokaç, A., 2004: Population parameters of Mullus barbatus in Izmir Bay (Aegean Sea), using length frequency analysis. J. Appl. Ichthyol. 20, 231233.

Pauly, D., 1980: On the interrelationships between natural mortality, growth parameters and mean environmental temperatures in 175 fish stocks. J. Cons. Int. Explor. Mer 39, 175-192.

Pauly, D., 1984: Fish dynamics in tropical waters, a manual for use with programmable calculators. ICLARM Reviews 8, Manila

Pauly, D., 1987: A review of the ELEFAN system for analysis lengthfrequency data in fish and aquatic invertebrates. In: Length-based methods in fisheries research, D. Pauly, G. R. Morgan (Eds). ICLARM Conf. Proc. 13. 7-34.

Pauly, D., 1990: Length-converted catch curves and the seasonal growth of fishes. Fishbyte 8, 33-38.

Pauly, D.; G. R. Morgan. (Eds), 1987: Length-based methods in fisheries research. ICLARM Conf. Proc. 13, 468.

Pauly, D.; Munro, J. L., 1984: Once more on growth comparison in fish and invertebrates. Fishbyte 2, 21.
Poole, W. R.; Reynold, J. D., 1996: Growth rate and age at migration of Anguilla anguilla. J. Fish Biol. 48, 633-642.

Quinn, J. T., II; Deriso, R. B., 1999: Quantitative fish dynamics. Oxford University Press, New York.

Robitaille, J. A.; Bérubé, P.; Tremblay, S.; Verreault, G., 2003: Eel fishing in the Great Lakes / St. Lawrence River system during the 20th century: Signs of overfishing. In: Biology, management, and protection of catadromous eels,A. D. Dixon, (Ed.). Amer. Fish. Soc. Symp. 33, 253-262.

Russell, I. C.; Potter, E. C. E., 2003: Implications of the precautionary approach for the management of the European eel, Anguilla anguilla. Fish. Manage. Ecol. 10, 395-401.

Shepherd, J. G., 1987: A weakly parametric method for estimating growth parameters from length composition data. In: Lengthbased methods in fisheries research, D. Pauly, G. R. Morgan, (Eds). ICLARM Conf. Proc. 13. pp. 113-119.

Svedäng, H., 1999: Vital population statistics of the exploited eel stock on the Swedish west coast. Fish. Res. 40, 251-265.

Tatsukawa, K., 2003: Eel resources in East Asia. In: Eel biology, K. Aida, K. Tsukamoto, K. Yamauchi (Eds). Springer Verlag, Tokyo, Japan, pp. 293-298

Tesch, F. W., 2003: The Eel. 3rd edn. Blackwell Science, Oxford.

Tseng, M. C.; Tzeng, W. N.; Lee, S. C., 2003: Historical decline in the Japanese eel Anguilla japonica in northern Taiwan inferred from temporal genetic variations. Zool. Stud. 42, 556-563.

Tsukamoto, K., 1992: Discovery of the spawning area for Japanese eel. Nature 356, 789-791.

Tsukamoto, K., 2006: Spawning of eels near a seamount: tiny transparent larvae of the Japanese eel collected in the open ocean reveal a strategic spawning site. Nature 493, 929.

Tzeng, W. N., 1997: Short- and long-term fluctuations in catches of elvers of the Japanese eel, Anguilla japonica. Developing and Sustaining World Fisheries Resources: the State of Science and Management. 2nd World Fisheries Congr. Proc., Victoria, Australia, pp. 85-89.

Tzeng, W. N.; Chang, C. W., 2001: Stock status and management prospect of freshwater eel Anguilla spp. in Taiwan. J. Taiwan Fish. Res. 9, 251-258.

Tzeng, W. N.; Lin, H. R.; Wang, C. H.; Xu, S. N., 2000: Differences in size and growth rates of male and female migrating Japanese eels in Pearl River, China. J. Fish Biol. 57, 1245-1253.

Tzeng, W. N.; Shiao, J. C.; Iizuka, Y., 2002: Use of otolith Sr:Ca ratios to study the riverine migratory behaviours of Japanese eel Anguilla japonica. Mar. Ecol. Prog. Ser. 245, 213-221.

Tzeng, W. N.; Iizuka, Y.; Shiao, J. C.; Yamada, Y.; Oka, H. P., 2003: Identification and growth rates comparison of divergent migratory contingents of Japanese eel (Anguilla japonica). Aquaculture 216, 77-86.

Velasco, G.; Reis, E. R.; Vieira, J. P., 2007: Calculating growth parameters of Genidens barbus (Silurifomes, Ariidae) using length composition and age data. J. Appl. Ichthyol. 23, 64-69.

Vøllestad, L. A., 1992: Geographic variation in age and length at metamorphosis of maturing European eel: environment effects and phenotypic plasticity. J. Anim. Ecol. 61, 41-48.

Weeder, J. A.; Uphoff, J. H. J., 2003: Effect of changes in growth and eel pot mesh size on American eel yield per recruit estimates in upper Chesapeake Bay. In: Biology, management, and protection of catadromous eels, A. D. Dixon (Ed.). Amer. Fish. Soc. Symp. 33, 169-176.

Author's address: Wann-Nian Tzeng, Institute of Fisheries Science, College of Life Science, National Taiwan University, Taipei, Taiwan 106, ROC.

E-mail address: wnt@ntu.edu.tw 